\title{
Prediction of academic dropout in university students using data mining: Engineering case
}

\author{
Autores \\ Jesús Silva, Luisa Fernanda Arrieta Matos, Claudia Medina Mosquera, Carlos Vargas Mercado, \\ Rosio Barrios González, Nataly Orellano Llinás, Omar Bonerge Pineda Lezama
}

\begin{abstract}
Student dropout is considered an important indicator for measuring social mobility and reflecting the social contribution that universities offer. In economic terms, there is evidence that students attribute their decision to defect from their academic programs because of their economic situation. Dropout causes significant waging gaps among people who complete their tertiary studies compared to those who do not, leading to a lack of skilled human capital that pays greater productivity to economic development of a country. Given the above, the objective of this study is to present a tree-based classification of decisions (CBAD) with optimized parameters to predict the dropout of students at Colombian universities. The study analyses 10,486 cases of students from three private universities with similar characteristics. The result of the application of this technique with optimized parameters achieved a precision ratio of $88.14 \%$.

Palabras clave

Student dropout, Classification based on decision trees, Optimization
\end{abstract}

